UDC 615.47:661.744.224

DOI: $10.21668 /$ health.risk/2020.1.13.eng

\title{
PECULIARITIES OF TOXIC EFFECTS PRODUCED BY DIISONONYL PHTHALATE AND REGULATION OVER IT IN POLYMER MATERIALS AND MEDICAL PRODUCTS
}

\author{
V.A. Hrynchak, S.I. Sychik
}

Scientific Practical Centre of Hygiene, 8 Akademicheskaya Str., Minsk, 220012, Belarus

\begin{abstract}
We chose diisononyl phthalate as our experimental research object; this compound is an isononyl ester of phthalic acid based on n-butene (CAS No. 28553-12-0).

Our research goal was to establish peculiarities and regularities related to toxic effects produced by diisononyl phthalate on experimental animals' bodies and give scientific substantiation for fixing its permissible quantities that could migrate from polymer materials and medical products.

We accomplished our research applying a set of toxicological, physiological, hematologic, biochemical, immunologic, cytogenetic, morphological, organoleptic, sanitary-chemical, and statistical techniques. We were the first to establish peculiarities of toxic impacts exerted by diisononyl phthalate after intragastric introduction into white rates. Those impacts were dosedependent toxic effects produced both on a whole body and specific organs and systems with typical disorders in functional and morphological parameters, cell differentiation, and an increase in number of cells with changes in their genetic apparatus.

We revealed that overall toxic effects as well as specific damaging ones produced by diisononyl phthalate on the endocrine and reproductive systems in experimental animals' bodies became apparent via functional disorders in the thyroid gland and gonads, embryogenesis, and offspring post-natal development. A chronic experiment allowed us to determine quantitative regularities and how toxic effects produced by diisononyl phthalate manifested themselves; so we were able to determine limiting parameters and a biological marker as well as fix a threshold of its hazardous impacts on a body, and substantiate fixing permissible quantities that could migrate from polymer materials and medical products. Our experiment results gave grounds for creating a hygienic standard for diisononyl phthalate that provided hygienic assessment and safe distribution of materials and medical products made of polymers that contained the compound.

Key words: diisononyl phthalate, plasticizer, toxicity, hazard, biological effects, laboratory animals, hygienic standard, medical products.
\end{abstract}

Modern policies in the sphere of chemical safety are aimed at reducing health risks caused by exposure to hazardous chemical factors; given that, it becomes vital to accomplish relevant primary prevention and to work out hygienic standards for such substances $[1,2]$. A special attention should be given to issues related to new polymer-based materials and products made of them being safely applied in medical practices [3]. Polyvinylchloride (PVC) is a widely used material; to produce it, phthalate plasticizers (PPs), or phthalic acid ethers, are applied as they make products made of PVC more elastic and flexible. When products made of PVC are used, PPs migrate into media that contact them hence there are no covalent bonds between a plasticizer and polymer molecules. Phthalates migration from medical products (blood storage containers, transfusion systems, tubes, catheters, etc.) is especially hazardous due to their direct impacts on internal media in a patient's body ${ }^{1}[4-7]$.

Over many years low-molecular PPs have been used in polymer products manufacturing;

(c) Hrynchak V.A., Sychik S.I., 2020

Vitaly A. Hrynchak - Candidate of Medical Sciences, Junior Researcher, Laboratory for Preventive and Environmental Toxicology (e-mail: grinchakva@gmail.com; tel.: +7 (017) 284-13-82; ORCID: https://orcid.org/0000-0002-4119-1793).

Sergey I. Sychik - Candidate of Medical Sciences, Associate Professor, Director (e-mail: rspch@rspch.by; tel.: +7 (017) 284-03-87; ORCID: https://orcid.org/0000-0002-5493-9799).

${ }^{1}$ Guide on designing polyvinylchloride-based compositions. R.F. Grossman ed. The 2nd edition, with amendments and corrections. Saint Petersburg, Nauchnye osnovy i tekhnologii Publ., 2009, 608 p. 
the most widely spread ones were dioctyl phthalate (DOP) and dibutyl phthalate (DBP). Both these substances had high migration capacities $[8,9]$. Multiple research results indicate that the said phthalates produce apparent toxic effects under long-term exposure and they primarily damage the reproductive and endocrine systems [10-14]. There are differences in state regulations over phthalates application in different countries including use of health risk assessment and scopes of permissible migration from products; DOP and DBP are completely forbidden in certain countries or their use is significantly limited.

Search for alternative PPs with improved technological properties and low migration capacities resulted in wide use of new highmolecular plasticizers; diisonyl phthalate (DIIP) is one of them. It has two isomers (CAS No. 68515-48-0 and No. 28553-12-0). Data taken from literature indicate that DIIP isomer CAS No. 28553-12-0 has a more branching carbon chain and is more widely used nowadays in manufacturing PVC and products made of it. The substance doesn't have a complete toxicological profile; regularities related to its dose-dependent toxic and specific effects produced on a body, specifically on the reproductive and endocrine systems, under long-term exposure haven't been studied; safe scopes of its migration from medical products haven't been substantiated.

Our research goal was to establish peculiarities and regularities of toxic effects produced by diisonyl phthalate on experimental animals and scientifically substantiate a standard for permissible scopes of its migration from polymer materials and medical products.

Data and methods. All the experiments were performed according to methodical guides $^{2,3}$ on 3 types of experimental animals: 106 white mice weighing from 18 to 22 grams; 352 random-bred white rats weighing from 180 to 210 grams; and 5 white rabbits weighing from 4.2 to 4.5 kilos.

We determined DIIP toxicometric parameters in acute experiments under intragastric, intraperitoneal, epicutaneous, and inhalation introduction into experimental animals. Capabilities to cumulate were examined in a sub-chronic experiment on white rats when DIIP was introduced into the stomach in doses varying from 100.0 to $10,000.0 \mathrm{mg} / \mathrm{kg}$ for 60 days. A chronic experiment that lasted 6 months involved intragastric DIIP introduction into white rats in doses varying from 0.01 to $1,000.00 \mathrm{mg} / \mathrm{kg}$.

All the experiments were accomplished in full conformity with the European Convention for the Protection of Vertebrae Animals used for Experimental and other Scientific Purposes (ETS No. 123) and Good Laboratory Practice (GLP) rules. Laboratory animals were taken out of experiments according to requirements fixed in the Use of Research Animals (1997).

Impacts exerted by DIIP on the reproductive function were examined as per a procedure developed by A.A. Dinerman [15]. We applied sagittal sections technique developed by W. Wilson and modified by A.P. Dyban [16] to determine and examine anomalies in internal organs of white rats embryos. Any possible irritating effects produced on undamaged skin and eye mucous membranes as well as sensitizing effects were examined according to the Guide No. 1.1.11-12-35-2004. We applied Ames test to estimate mutagenic activity [17]. Meta-phase analysis of chromosome aberrations in bone marrow cells and spleen cells was performed on mice ${ }^{4}$. We examined ge-

\footnotetext{
${ }^{2}$ Guide 2.1.5.11-10-199-2003. Substantiation of hygienic standards for chemicals contents in water taken from water objects used for communal and drinking water supply. Approved by the Order of the Belarus Chief Sanitary Inspector on December 12, 2003 No. 160. The collection of sanitary rules and standards on drinking water supply. Minsk, 2005, Part 2, pp. 120-167.

${ }^{3}$ Guide 1.1.11-12-35-2004. Requirements to accomplishing experimental research for primary toxicological assessment and hygienic standardization of substances. Approved by the Belarus Public Healthcare Ministry on December 14, 2004. Minsk, 2004, 43 p.

${ }^{4}$ Guide $055-1215$. How to determine mutagenic effects produced by chemical products (chemical substances and their mixtures). Approved by the Order of the Belarus Chief Sanitary Inspector on August 30, 2016. E.S. Yurkevich eds. Minsk, Theoretical and practical center for hygiene Publ., 2015, pp. 10-15.
} 
netic structures of white rats' leucocytes in sub-chronic and chronic experiments via making smears as per a procedure developed by J.N. Mills [18]. Organoleptic and sanitarychemical parameters applied for determining limiting hazard properties were examined according to the Guide ${ }^{5}$.

All the obtained data were statistically processed with conventional analysis techniques applying MS Excel and STATISTICA 10 software. Discrepancies between experiment and control groups were taken as statistically significant at $\mathrm{p}<0.05$.

Experimental data on DIIP toxic properties can be applied when establishing safety parameters as per acceptable health risk.

Results and discussion. We didn't register any intoxication and deaths among experimental animals in acute experiments involving intragastric DIIP introduction into animals of both sexes in maximum possible doses. The same results were obtained when DIIP was either applied on skin or introduced intraperitoneally. We didn't establish any potential hazards caused by inhalation exposure and subsequent acute intoxication in experiments on mice due to low volatility of the substance. We couldn't calculate average lethal doses and concentrations due to absence of any deaths in the above mentioned experiments (Table).

We didn't reveal any irritating effects produced on undamaged skin and eye mucous membranes of laboratory animals after a single epicutaneous exposure to DIIP. We also didn't detect any sensitizing effects produced by DIIP in experiments that modeled delayed hypersensitivity in white mice.

In another experiment DIIP was repeatedly introduced intragastrically into white rats in doses equal to $10,000.00,1,000.00$, and $100.0 \mathrm{mg} / \mathrm{kg}$; the substance didn't have any apparent cumulative properties that could be equal to lethal effects but exerted general toxic polytropic impacts. Disorders in the nervous

\begin{tabular}{|c|c|c|c|}
\hline Parameters & $\begin{array}{c}\text { Animal } \\
\text { type }\end{array}$ & $\begin{array}{l}\text { Dose, } \\
\mathrm{mg} / \mathrm{kg}\end{array}$ & Classification \\
\hline \multirow{2}{*}{$\begin{array}{l}\text { Average lethal } \\
\text { dose under intra- } \\
\text { gastric introduc- } \\
\text { tion }\end{array}$} & rats & & \multirow{3}{*}{$\begin{array}{l}\text { IV hazard } \\
\text { category, } \\
\text { low hazard }\end{array}$} \\
\hline & mice & $>5,000.0$ & \\
\hline $\begin{array}{l}\text { Average lethal } \\
\text { dose under } \\
\text { epicutaneous } \\
\text { introduction }\end{array}$ & rats & $>2,500.0$ & \\
\hline \multirow{2}{*}{$\begin{array}{l}\text { Average lethal } \\
\text { dose under in- } \\
\text { traperitoneal in- } \\
\text { troduction }\end{array}$} & rats & & \multirow{2}{*}{$\begin{array}{c}\text { VI toxicity } \\
\text { category, } \\
\text { relatively } \\
\text { harmless [19] }\end{array}$} \\
\hline & mice & $>3,000.0$ & \\
\hline
\end{tabular}

system became apparent via changes in motor activity of laboratory animals: there was 2.9 times decrease in a parameter called "passing through sectors" after exposure to $10,000.00 \mathrm{mg} / \mathrm{kg}$ of DIIP, but the parameter grew by 1.8 times under exposure to $100.00 \mathrm{mg} / \mathrm{kg}$ $(p<0.05)$. We analyzed parameters of experimental rats' peripheral blood under exposure to $10,000.0 \mathrm{mg} / \mathrm{kg}$ and revealed signs of irondeficiency anemia, namely, erythropenia, decreased haematocrit contents, lower erythrocytes volumes, lower hemoglobin concentration and contents in an erythrocyte. There was also a statistically significant 3.0 times decrease in iron contents in blood serum under exposure to the maximum dose and 2.4 times decrease after the dose was 10 times lower against the control group.

We revealed some disorders in the mineral metabolism in a sub-chronic experiment when DIIP was introduced into rats in doses equal to $10,000.0$ and $1,000.0 \mathrm{mg} / \mathrm{kg}$; there was $1.2-1.4$ times decrease in calcium contents in blood serum $(\mathrm{p}<0.05)$ due to its $5.2-8.6$ times more intense excretion with urine $(\mathrm{p}<0.05)$ against the control group. Phosphor contents, on the contrary, grew by $30.6-33.3 \%(p<0.05)$ as its excretion with urine went down by 2.3-9.1 times

\footnotetext{
${ }^{5}$ Guide 1.1.10-12-41-2006. Hygienic assessment of medical products, medical appliances and materials used in their manufacturing / Approved by the Order of the Belarus Chief Sanitary Inspector on November 22, 2006 No. 155. The collection of regulatory documents on toxicology. Minsk, 2007, part. 3, pp. 27-93.

${ }^{6}$ GOST 12.1.007-76. Hazardous substances. Classification and overall safety requirement (Introduced on January 01, 1977). Minsk, BelGISS Publ., 2008, 8 p.
} 
against the control group $(\mathrm{p}<0.05)$ after exposure to all experimental doses.

There were also disorders in kidney functions after repeated exposure to DIIP in the above mentioned doses; it became obvious due to a statistically significant $1.9-3.9$ times growth in diuresis in the test groups together with a decrease in uric acid contents (by 2.5-4.2 times), urea (by 1.5-2.1 times), and creatinine (by 2.0-3.1 times) against the control group. After exposure to DIIP in a dose equal to $10,000.00 \mathrm{mg} / \mathrm{kg}$ we revealed a 1.2 times decrease in kidneys volume in animals from the test group $(p<0.05)$ and a 1.7 times increase in excretion of magnesium with urine $(p<0.05)$ against the control group. All the above mentioned changes were accompanies with structural disorders in the kidneys, in particular, dystrophy and inflammation.

We analyzed enzyme activity of white rats' blood serum after DIIP doses were introduced into them and statistically processed the results; it allowed us to reveal that gammaglutamyl transpeptidase contents grew by $12.5-17.6 \%(p<0.05)$, asparagine aminotransferase contents went down by 1.5 times, and $\alpha$-amylase contents grew by 1.4 times against the control group at $\mathrm{p}<0.05$.

We performed morphologic examinations of experimental rats' livers and revealed dystrophic changes in hepatocytes, interstitial hepatitis signs, and a 1.2-1.6 times increase in the organ volume $(\mathrm{p}<0.05)$ under exposure to DIIP in doses equal to $10,000.0$ and $1,000.0 \mathrm{mg} / \mathrm{kg}$. Functional disorders in the spleen became obvious via hyperplasia of lymphoid follicles in white pulp, hyperemia, and reactive proliferation of red pulp together wuth 1.4 times growth in the organ volume $(p<0.05)$ against the control group. Signs of gastritis and interstitial pancreatitis were also morphologically revealed in animals from the test group.

We analyzed hormonal state of experimental animals under sub-chronic oral exposure to DIIP in doses ranging from $10,000.00$ to $100.0 \mathrm{~ms} / \mathrm{kg}$ and didn't reveal any statistically significant changes. However, morphologic and morphometric examinations revealed a dose-dependent decrease in the diameter of the thyroid gland follicles that was 1.3-2.3 times smaller $(p<0.05)$ and there were signs of diffuse toxic goiter and hyperplasia of the adrenal cortex as it became 1.3-1.8 times thicker $(\mathrm{p}<0.05)$.

We performed cytogenetic analysis of experimental rats' peripheral blood after a subchronic experiment was over; the analysis revealed there was an increase in number of leucocytes with morphological signs of necrotic death; this number was 5.1-6.1 times higher than in animals from the control group $(p<0.05)$ after exposure to DIIP in doses equal to $10,000.0$ and $1,000.0 \mathrm{mg} / \mathrm{kg}$.

We performed a 180-day experiment on white rats (6 test groups and 1 control group) that involved intragastric DIIP introduction in doses ranging from 0.01 to $1,000.0 \mathrm{mg} / \mathrm{kg}$; there were no external evidence of intoxication or any behavioral disorders during the experiment. As the experiment was over, we revealed toxic effects produced by DIIP that had poly-systemic nature; their evidence depended on introduced doses. Thus, after exposure to doses varying from $1,000.0$ to $1.0 \mathrm{mg} / \mathrm{kg}$, experimental rats had statistically significant changes in their peripheral blood: leucopenia; lymphocytes contents decreased by $1.5-2.0$ times; monocytes, 1.3-1.4 times; granulocytes, 1.5-1.6 times; average hemoglobin concentration in erythrocytes went down by $5.0-5.8 \%$; average thrombocytes volume, by $7.9-13.3 \%$; thrombocytosis occurred after exposure to a dose equal to $1,000.0 \mathrm{mg} / \mathrm{kg}$.

Exposure to DIIP in doses ranging from $1,000.0$ to $0.1 \mathrm{mg} / \mathrm{kg}$ resulted in renal toxic effects that became obvious via lower iron excretion with urine, glycosuria occurrence, and morphological changes in the kidneys such as dystrophy of proximal tubules epithelium with interstitial nephritis signs. Special attention should be paid to more intense excretion of magnesium from a body as its contents was 2.0-3.3 times higher in urine of animals from all the test groups $(\mathrm{p}<0.05)$ against the control group after exposure to all the experimental doses varying from $1,000.0$ to $0.01 \mathrm{mg} / \mathrm{kg}$.

We analyzed biochemical parameters of experimental animals' blood serum under exposure to DIIP in doses varying from $1,000.0$ to $10.0 \mathrm{mg} / \mathrm{kg}$ and revealed a statistically significant 2.1-5.4 times decrease in iron contents 
and 1.2-1.4 times decrease in phosphor contents together with 2.0 times increase in calcium contents against the control group at $p<0.05$.

DIIP produced obvious toxic effects on the liver in doses equal to $1,000.0$ and 100.0 $\mathrm{mg} / \mathrm{kg}$ as the organ became smaller in its size by 19.1 and $15.8 \%(p<0.05)$, contents of high density lipoproteins went down by 7.1 and $8.3 \%$ accordingly $(\mathrm{p}<0.05)$, and urea contents grew by 1.2 times $(p<0.05)$; there were also signs of interstitial hepatitis and dystrophic changes in hepatocytes.

As for hormonal state of white rats after exposure to DIIP in doses varying from $1,000.0$ to $1.0 \mathrm{mg} / \mathrm{kg}$, the most apparent changes were revealed in contents of thyroxin and thyrotrophic hormone in blood serum as they increased by 2.1-3.3 times and 1.8-2.5 times accordingly against the control group $(\mathrm{p}<0.05)$. An increase in free thyroxin contents was statistically significant only after exposure to doses equal to $10.0 \mathrm{mg} / \mathrm{kg}$ and higher; free triiodothyronine, after exposure to a dose equal to $1,000.0 \mathrm{mg} / \mathrm{kg}$. Pathomorphological disorders were revealed in the thyroid gland of experimental animals after exposure to DIIP in doses varying from 1,000.0 to $1.0 \mathrm{mg} / \mathrm{kg}$; they were an increase in follicles size and changes in their epithelium. There were no such changes after exposure to smaller doses.

Anti-androgenic effects produced by DIIP in doses varying from $1,000.0$ to $1.0 \mathrm{mg} / \mathrm{kg}$ became apparent via an authentic 2.6-3.9 time decrease in testosterone contents in blood serum of experimental animals and an ascending trend in contents of progesterone, estradiol, lutropin, and collicle-stimulating hormones ( $\mathrm{p} \geq 0.05)$ against the control group.

We didn't detect any changes in contents of hydrocortisone and dehydroepiandrosterone (adrenal cortex hormones) in blood serum of experimental animals. Morphometric examinations revealed that adrenal cortex increased by 3.0-3.8 times in experimental animals $(p<0.05)$ and the organ volume grew by 1.6 times under exposure to DIIP in a dose equal to $1,000.0$ $\mathrm{mg} / \mathrm{kg}$ at $\mathrm{p}<0.05$. We didn't reveal any changes in hormonal state of white rats under multiple exposure to DIIP in a dose equal to $0.1 \mathrm{mg} / \mathrm{kg}$ and it allows us to consider this dose as a noneffective one as per a specific sign.
We didn't reveal any disorders in nonspecific humoral immunity as per contents of complement components $(\mathrm{C} 3, \mathrm{C} 4)$ and immunoglobulins $\mathrm{A}, \mathrm{G}$, and $\mathrm{M}$ in blood serum of white rats after DIIP introduction in all series of experiment.

We performed morphological examinations of the gastric mucosa and pancreas mucosa of rats under exposure to DIIP in doses varying from $1,000.0$ to $1.0 \mathrm{mg} / \mathrm{kg}$ and revealed reactive hyperplasia in the gastric epithelium and chronic gastritis occurrence with progressive 1.2-1.4 times growth in thickness of multi-layer pavement epithelium of the gastric mucosa $(p<0.05)$; we also detected signs of interstitial pancreatitis with Langerhans cells hyperplasia.

We performed cytogenetic analysis of leukocytes taken from blood of experimental animals after a chronic experiment was over and established that DIIP in doses varying from $1,000.0$ to $1.0 \mathrm{mg} / \mathrm{kg}$ was able to produce damaging effects on genetic structures such as enhanced cellular proliferation with simultaneous growth in numbers of micronucleuses and cells with necrosis signs and a decrease in contents of young forms.

Consequently, the results obtained via complex clinical-biological, morphological, morphometric and cytogenetic research indicate that DIIP doses which vary from 1,000.0 to $0.1 \mathrm{mg} / \mathrm{kg}$ and are intragastrically introduced in chronic experiments produce general toxic effects on a body. A dose equal to 0.01 $\mathrm{mg} / \mathrm{kg}$ can be taken as chronic exposure threshold and its limiting parameter is a nephrotoxic effect related to excretion of magnesium with urine (a biological marker). Toxic effects produced on the endocrine system were revealed under exposure to DIIP when it was introduced into experimental animals in a dose which was 100 times higher than the chronic exposure threshold.

Experimental study of remote effects produced by exposure to DIIP on a body involved examining reproductive toxicity (embryotropic, teratogenic, and gonadotropic effects) as well as occurrence of mutagenic and cytotoxic properties.

Exposure to DIIP after intragastric introduction in a dose equal to $10,000.0 \mathrm{mg} / \mathrm{kg}$ during pregnancy resulted in statistically signifi- 
cant 3.5 times growth in overall embryonic and post-implantation mortality (up to $29 \%$ ) and occurrence of multiple (combined) malformations.

When introduced DIIP doses were reduced to $100.0 \mathrm{mg} / \mathrm{kg}$, there was also a decrease in quantity of embryonic malformations (microphthalmia in $4.8 \%$ ); there were no such malformations when doses went down to $10.0 \mathrm{mg} / \mathrm{kg}$.

We observed post-natal development of offspring born by female white rats that had been exposed to DIIP in a dose equal to $10,000.0 \mathrm{mg} / \mathrm{kg}$ during pregnancy; mortality among infants rats grew by $22.7 \%(p<0.05)$. We also examined hormonal state of male offspring on the $60^{\text {th }}$ day of the experiment after exposure to DIIP in doses equal to $1,000.0$ and $100.0 \mathrm{mg} / \mathrm{kg}$ and revealed functional disorders in the thyroid gland and gonads. Those disorders became apparent via a growth in crude thyroxin contents (by 2.0 and 2.3 times, $\mathrm{p}<0.05$ ) and thyrotrophic hormone (by 2.1 and 2.3 times, $\mathrm{p}<0.05$ ) in blood serum as well as a decrease in testosterone concentration (by 2.3 and 2.9 times, $\mathrm{p}<0.05$ ) accordingly against the control. But still, there were no significant changes in morphofucntional parameters of male rats' gonads (volumes of testicles and appendages, overall sperm concentration, motile and immotile sperm concentration, average velocity of motile sperm) $[20,21]$.

We didn't detect any functional disorders in pubescent male white rats in experiments involving research on effects produced on gonads after 2-month intragastric DIIP introduction in doses varying from $10,000.0$ to $100.0 \mathrm{mg} / \mathrm{kg}$. However, morphological research on testicles performed after 60-daty exposure revealed a decrease in spermatogenesis of experimental rats and reduced sizes of testicular tubules together with reduced number of layers and cellularity. At the same time spermatogenesis ended with spermatocides and spermatids. The same changes were detected when exposure to DIIP in doses varying from $1,000.0$ to $1.0 \mathrm{mg} / \mathrm{kg}$ was extended to 6 months. Under exposure to the maximum experimental dose a number of mature sperm in testicular tubules of experimental animals went down by 5.4 times $(p<0.05)$ against the control group.

Consequently, experiments allowed establishing that there was a cause-and-effect relation between reproductive function disorders in white rats under exposure to DIIP and introduced doses, $0.1 \mathrm{mg} / \mathrm{kg}$ being the non-effective one.

We estimated mutagenic effects produced by DIIP with Ames test on Salmonella typhimurium strains TA 98, TA 100, TA 1535, TA 97, and $T A 102$ in concentrations equal to $0.3,0.6$, 13., 2.5 , and $5.0 \mathrm{mg} / \mathrm{ml}$ with metabolic activation and without it; the results indicated there were no such effects. We analyzed cytogenetic specimen of the bone marrow and spleen after 24 hours had passed from a single intraperitoneal introduction of DIIP into white mice in a dose equal to $2,000.0 \mathrm{mg} / \mathrm{kg}$; we didn't reveal any increase in chromosome aberrations. We also didn't establish any discrepancies between the test and control groups as per quantity of cells with apoptosis signs (interphase death) and polyploids in the bone marrow. However, spleens of white mice from the test groups contained a statistically 5.0 times lower number of cells with apoptosis signs and 4.0 times higher number of polyploids against the control group $(\mathrm{p}<0.05)$.

Therefore, DIIP didn't produce any mutagenic effects as per number of chromosome aberrations after a single intraperitoneal introduction into white mice; still, the substance caused changes in division, differentiation, and death of cells in the spleen. It can possibly occur due to active proliferating cells in a body of a warm-blooded animal, including embryonic ones, being most susceptible to cytotoxic effects produced by DIIP. It can be a possible mechanism of embryotoxic (teratogenic) effects produced by DIIP. Impacts on the reproductive and endocrine systems revealed in our experiments are secondary in their nature and occur due to damaging effects produced by DIIP on a body as a result of structural and functional changes in cells.

Permissible DIIP migration into model media (distilled water) is a parameter that determines safety of polymer-based materials and medical products. A safe standard was calculated according to methodical approaches on substantiating hygienic standards for chemicals contents in water with determining a limiting hazard criterion as per organoleptic, overall sanitary, and toxicological parameters. 
We examined impacts exerted by DIIP on standardized organoleptic and overall sanitary water parameters under its maximum attainable concentration in water that was equal to $0.6 \mathrm{mg} / \mathrm{dm}^{3}$. We didn't reveal any impacts exerted by DIIP in this concentration on such water parameters as smell, taste, turbidity, color, foaming, permanganate oxidability, susceptibility to being bromated, and some others. Therefore, the tested concentration was non-effective.

At the same time, a threshold dose equal to $0.01 \mathrm{mg} / \mathrm{kg}$ was established in a chronic experiment on white rats that involved examining toxic effects produced by DIIP under intragastric introduction as per a limiting parameter related to nephrotoxic impacts.

Maximum non-effective concentration calculated as per toxic hazard criterion amounted to $0.02 \mathrm{mg} / \mathrm{dm}^{3}$ taking into account safety coefficient equal to 10 , average human body weight, and a volume of daily water consumption. However, it seems impossible to determine this DIIP concentration in model media as contemporary techniques for control over its contents have sensitivity equal to $0.05 \mathrm{mg} / \mathrm{dm}^{37}$. Bearing that in mind, a standard for permissible DIIP migration was substantiated and fixed; it contained a "nonpermissible" value $\left(<0.05 \mathrm{mg} / \mathrm{dm}^{3}\right)$ and it ensures sanitary-hygienic control and safe use of polymer-based materials and medical products that contain DIIP.
Conclusions. Complex toxicological and hygienic research allowed obtaining complete toxicological assessment of DIIP in acute, subchronic, and chronic experiments under intragastric introduction into experimental animals. We determined polytropic nature of overall toxic dose-dependent effects produced by DIIP on organs and tissues and specific damaging effects produced on the endocrine and reproductive systems of experimental animals. Chronic experiments allowed revealing quantitative regularities and specific features of toxic effects produced by DIIP; they also allowed establishing a nephrotoxic limiting parameter and biological markers of leading adverse impacts exerted by DIIP on a body. We took a toxicity criterion for substantiating and fixing a standard for permissible DIIP migration from polymer materials that could ensure relevant hygienic assessment and safe use of polymerbased materials containing DIIP and medical products made of such materials.

Revealed peculiarities and regularities of toxic effects produced by DIIP can be applied to determine reference safe contents and concentrations as per acceptable health risk criteria.

Funding. The research was not granted any financial support.

Conflict of interests. The authors declare there is no any conflict of interests.

\section{References}

1. Onishchenko G.G. Chemical safety is the most important constituent of the sanitary and epidemiological well-being of population. Toksikologicheskii vestnik, 2014, vol. 124, no.1, pp. 2-6 (in Russian).

2. Sychik S.I., Shevchuk L.M., Itpaeva-Lyudchik S.L., Ivko N.A. Osnovnye itogi deyatel'nosti respublikanskogo unitarnogo predpriyatiya «Nauchno-prakticheskii tsentr gigieny»: 2011 g. - 1 polugodie 2016 g. [Basic results of activities performed by the Republican Scientific and Practical Center for Hygiene over 2011 - the 1st half of 2016]. Zdorov'e i okruzhayushchaya sreda: sbornik nauchnykh trudov. In: S.I. Sychik ed. Minsk, Nauchno-prakticheskii tsentr gigieny, 2017, vol. 26, pp. 290-294 (in Russian).

3. Balan G.M., Kharchenko T.F., Levitskaya V.N., Isaeva S.S., Kharchenko O.A., Bubalo N.N., Povyakel' L.I. Potentsial'nyi risk dlya zdorov'ya ftalatnykh plastifikatorov polivilkhlorida (sovremennye aspekty) [Potential health risk caused by phthalate plasticizers based on polyvinyl chloride (contemporary aspects)]. Ukrainskii zhurnal sovremennykh problem toksikologii, 2013, no. 1-2, pp. 38-47 (in Russian).

4. Koo J.W., Parham F., Kohn M.C., Masten S.A., Brock J.W., Needham L.L., Portier C.J.The association between biomarker-based exposure estimates for phthalates and demographic factors in a human reference population. Environmental Health Perspectives, 2002, vol. 110, no. 4, pp. 405-410. DOI: 10.1289/ehp.02110405

${ }^{7}$ GOST R ISO 14389-2016.Textile materials. Determination of phthalate contents. A procedure involving tetrahydrofuran application (Introduced on April 01, 2017). Moscow, Standartinform Publ., 2016, 16 p. 
5. Predlagaemaya strategiya, napravlennaya na usilenie vovlechennosti sektora zdravookhraneniya v osushchestvlenie Strategicheskogo podkhoda [A proposed strategy aimed at making public healthcare structures more involved into Strategic approach implementation]. Doklad Mezhdunarodnoi konferentsii po regulirovaniyu khimicheskikh veshchestv o rabote ee tret'ei sessii. Nairobi, Keniya: Programma OON po okruzhayushchei srede (UNEP), 2012, pp. 72-85 (in Russian).

6. Gore A.C., Chappell V.A., Fenton S.E., Flaws J.A., Nadal A., Prins G.S., Toppari J., Zoeller R.T. EDC-2: The Endocrine Society's Second Scientific Statement on Endocrine-Disrupting Chemicals. Endocrine Reviews, 2015, vol. 36, no. 6, pp. E1-E150. DOI: 10.1210/er.2015-1010

7. Endocrine Disrupting Chemicals-2012: Summary for Decision-Makers. In: Å. Bergman, J.J. Heindel, S. Jobling, K.A. Kidd, R.T. Zoeller eds. Geneva, World Health Organization, 2013, 38 p.

8. Zoeller R.T., Brown T.R., Doan L.L., Gore A.C., Skakkebaek N.E., Soto A.M., Woodruff T.J., Vom Saal F.S. Endocrine-disrupting chemicals and public health protection: a statement of principles from the Endocrine Society. Endocrinology, 2012, vol. 153, no. 9, pp. 4097-4110. DOI: 10.1210/en.2012-1422

9. Global Status Report on Noncommunicable Diseases 2014. Geneva, World Health Organization, 2014, $299 \mathrm{p}$.

10. The European health report 2012: charting the way to well-being. World Health Organization, 2013. Available at: http://www.euro.who.int/data/assets/pdf_file/0004/197113/EHR2012-Eng.pdf(20.02.2019).

11. Lazareva V.A., Kuchugurnyi V.E., Bortnikova E.A. Plastifikatory: marketingovyi obzor [Plasticizers: a marketing review]. Cherkassy, GP «Cherkasskii NIITEKhIM» Publ., 2011, 478 p. (in Russian).

12. Sinitsyna O.O., Rakhmanin Yu.A., Zholdakova Z.I., Aksenova M.G., Kirillov A.V., Burd S.G., Il'yukova I.I. Epidemiological, toxicological and molecular-genetic aspects of endocrine disrupting chemicals in the chemical safety problem. Gigiena $i$ sanitariya, 2018, vol. 97, no. 3, pp. 197-203 (in Russian).

13. European Union Risk Assessment Report 1,2-benzenedicarboxylic acid, di-C8-10-branched alkyl esters, C9-rich and di-isononyl phthalate (DINP). Risk assessment.Luxembourg, Office for Official Publications of the European Communities, 2003, 302 p.

14. Evaluation of new scientific evidence concerning DINP and DIDP in relation to entry 52 of Annex XVII to REACH Regulation (EC) No 1907/2006: Final review report. Helsinki, European Chemicals Agency, 2013, 369 p.

15. Dinerman A.A. Rol' zagryaznitelei okruzhayushchei sredy v narushenii embrional'nogo razvitiya: monografiya [Role played by environmental contaminants in embryonic development disorders: a monograph]. Moscow, Meditsina Publ., 1980, 192 p. (in Russian).

16. Dyban A.P., Baranov V.S., Akimov I.M. Osnovnye metodicheskie podkhody k testirovaniyu teratogennoi aktivnosti khimicheskikh veshchestv [Basic methodical approaches to testing teratogenic effects produced by chemicals]. Arkhivanatomii, gistologi i iembriologii, 1970, vol. 59, no. 10, pp. 89-100 (in Russian).

17. Mortelmans K., Zeiger E. The Ames Salmonella/microsome mutagenicity assay. Mutation Research, 2000, vol. 455, no. 1-2, pp. 29-60. DOI: 10.1016/s0027-5107(00)00064-6

18. Mills J.N. Interpreting blood smears (or What blood smears are trying to tell you!). Australian veterinary journal, 1998, vol. 76, no. 9, pp. 596-600. DOI: 10.1111/j.1751-0813.1998.tb10235.x

19. Sidorov K.K. O klassifikatsii toksichnosti yadov pri parenteral'nykh sposobakh vvedeniya [On classifying toxicity of poisons under parenteral introduction]. Toksikologiya novykh promyshlennykh khimicheskikh veshchestv: sbornik statei. Moscow, Meditsina Publ., 1973, vol. 13, pp. 47-51 (in Russian).

20. Grynchak V.A., Sychik S.I. Peculiarities of the toxic effect of diisononyl phthalate plasticizer phthalate on experimental models. Gigiena i sanitariya, 2018, vol. 97, no. 5, pp. 474-477 (in Russian).

21. Grynchak V.A., Sychik S.I., Vlasenko E.K., Il'yukova I.I., Afonin V.Yu. The Peculiarities of the Embryotoxic Action of Diisononyl Phthalate in Experiments on Laboratory Animals. Vestnik Vitebskogo gosudarstvennogo meditsinskogo universiteta, 2018, vol. 17, no. 4, pp. $72-77$ (in Russian).

Hrynchak V.A., Sychik S.I. Peculiarities of toxic effects produced by diisononyl phthalate and regulation over it in polymer materials and medical products. Health Risk Analysis, 2020, no. 1, pp. 118-125. DOI: 10.21668/health.risk/2020.1.13.eng

Received: 23.09.2019

Accepted: 03.02.2020

Published: 30.03.2020 